\title{
Whose Life Is It Anyway? A study in respect for autonomy
}

\author{
Margaret Norden Marymount University, Arlington, Virginia, USA
}

\begin{abstract}
Brian Clark's drama, Whose Life Is It Anyway? (1), explores the difficulties of applying the principle of respect for autonomy to real-life circumstances. In the play a permanently disabled patient, who wishes to be allowed to die, raises moral questions about the adequacy of the autonomous agent, respect for the autonomy of others, the authority of the law, the allocation of society's resources, and the intrinsic value of human life. After a brief review of the story and definition of respect for autonomy, this paper cites passages from the play that dramatize the tension between respect for autonomy and these other moral concerns. There follows a review of relevant commentary from the classicists Kant and Mill and the modernists Childress and Gillon. The study concludes that although classical and contemporary philosophers have clarified and elaborated upon the relationship between ethical principles, they have not provided definitive guidelines.
\end{abstract}

\section{Introduction}

The principle of respect for autonomy is generally accepted; however, several ethical dilemmas are posed when this principle is applied to a real life situation. The play, Whose Life Is It Anyway?, explores these questions. After a brief review of the story and definition of the principle of respect for autonomy, this paper discusses the potential tension between this precept and the other moral concerns that surface in the story. These issues are: respect for the autonomy of others; the intersection of the law, medicine and philosophy; the allocation of society's resources; and the intrinsic value of human life. References to the philosophical commentaries of the classical philosophers Kant and Mill, and the contemporary philosophers Childress and Gillon are cited in an attempt to clarify the issues.

\section{Key words}

Bioethics; attitudes towards death; care of the dying patient.

\section{Precis of the story}

Whose Life Is It Anyway? opens with the hospitalization of Ken Harrison who was critically injured in an automobile accident four months earlier and permanently paralyzed from the neck down. Although Ken arrived in critical condition, he has since been stabilized, informed by his doctors that his paralysis is permanent, and advised that he will be transferred to a long-term care facility. Facing the prospect of such an existence, Ken chooses not to live. He realizes that he could not survive outside of an institution, and therefore, requests a discharge.

Although a psychiatrist confirms Ken's mental competence, the hospital doctors refuse to discharge him. He subsequently sues and wins. Spared of all further treatment, Ken is left alone to die.

\section{Respect for autonomy}

Ken's contention that he had the right to decide to end his own life, was based on the moral requirement that people respect another's autonomy. The following passages illustrate his stance.

Ken: I know that our hospitals are wonderful. I know that many people have succeeded in making good lives with appalling handicaps. I'm happy for them and respect and admire them. But each man must make his own decision. And mine is to die quietly and with as much dignity as I can muster (2).

Ken: The cruelty doesn't reside in saving someone or allowing them to die. It resides in the fact that the choice is removed from the man concerned ... If I choose to live it would be appalling if society killed me. If I choose to die, it is equally appalling if society keeps me alive ... dignity starts with his [a person's] choice. Without it, it [keeping a person alive] is degrading because technology has taken over from the human will (3).

In the eighteenth century Immanuel Kant defined autonomy as moral freedom, the crucial element of man's moral identity. Kant wrote that free and equal human beings rationally impose, and therefore 
accept, moral principles and constraints. '... The nature of rational beings themselves and of the moral law which their reason discerns requires that the autonomy of all be respected' (4). John Stuart Mill defined personal autonomy more as a political and social condition than as a moral one. Along with his fellow utilitarians, Mill considered individual liberty essential to human development and happiness, and therefore, good for society as a whole. Mill maintained that 'neither one person, nor any number of persons, is warranted in saying to another human creature ... that he shall not do with his life for his own benefit what he chooses to do with it. He is the person most interested in his own well-being ... with respect to his own feelings and circumstances, the most ordinary man or woman has means of knowledge considerably surpassing those that can be possessed by anyone else' (5). Kant and Mill then, although they differ in reasoning, find that man's autonomy is based on his rationality. They agree on the moral importance of respecting that autonomy.

\section{Challenges posed by other moral concerns}

Putting this generally accepted principle into effect raises ethical questions which are dramatized by Clark's play. One such question is whether or not the agent is adequately autonomous. Ken's story focuses on mental incompetence as a potential restraint to respecting autonomy.

Ken: I've decided not to stay alive.

Dr Emerson: But you can't decide that.

Ken: Why not?

Dr Emerson: You're very depressed (6).

Dr Emerson: Can't you understand that Mr Harrison is suffering from depression? He is incapable of making a rational decision about his life and death. Hill: Are you maintaining that $\mathrm{Mr}$ Harrison is mentally unbalanced?

Dr Emerson: Yes (7).

Dr Emerson: It's impossible to injure the body to the extent that $\mathrm{Mr}$ Harrison did and not affect the mind. It is common in these cases that depression and the tendency to make the wrong decision goes on for months, even years (8).

Fudge: ... however much we may sympathize with $\mathrm{Mr}$ Harrison in his cogently argued case to be allowed to die, the law instructs us to ignore it if it is the product of a disturbed or clinically depressed mind (9).

The drama also emphasizes that ignorance may render the agent inadequately autonomous.

Ken: ... black magic is no longer of much use ... people can and want to understand what's wrong with them and many of them can make decisions about their own lives.

Dr Travers: What they need is information.

Ken: Of course, but as a rule, doctors dole out information like a kosher butcher gives out pork sausages ... I should be grateful for information so that I can make a decision (10).

Most philosophers agree that insanity, immaturity, and the potential of causing oneself harm are? justifiable constraints to respect for autonomy. $\vec{\omega}$ However, they are ambiguous on the subject of $\stackrel{\omega}{\mathscr{\rho}}$ mental illness. Mill excluded those not in the $\overline{\overline{3}}$ maturity of their faculties, without the ordinary amount of understanding ... who behaved incompatibly with the full use of the reflecting faculty' from the right to individual liberty (11). The $\overrightarrow{0}$ contemporary philosophers Gillon and Childress 0 devote more attention to the potential constraints of mental incompetence and ignorance. Raanan Gillon $\vec{c}$ defines autonomy as deliberated self-rule or selfdetermination, and maintains that the requirement to respect autonomy may be overridden if the intent, available information, or the mental capacity to acquire and assimilate that information and make a decision is sufficiently diminished (12). Gillon specifies that the moral obligation to respect autonomy requires that physicians give patients as much information as they want. Childress too stresses that mental incompetence and lack of $\overrightarrow{\overrightarrow{0}}$ information limit the application of respect for $\stackrel{3}{\exists}$ autonomy. He discusses the levels of autonomy and the difficulty in determining when a person is considered competent.

Respect for the individual's autonomy may also be challenged by the principle of respect for the autonomy of others. In Clark's play, Ken's autonomous choice clashes with the physician's autonomy in carrying out his professional obligation to benefit, rather than harm, a patient.

Dr Emerson: But in spite of two qualified opinions (to administer medication), you accept the decision of $\tilde{N}$ someone completely unqualified to take it.

Dr Scott: He may be unqualified, but he is the one affected.

Dr Emerson: Ours was an objective, his a subjective decision (13).

fudge: When then do you think he [the doctor] came? to that opinion?

Ken: He's a good doctor and won't let a patient die if he can help it (14).

Classical philosophy enjoins against doing physical harm to others, and Kant lists beneficence as man's $\delta$ duty (15). However, the concept that one individual's autonomy may interfere with the rights of another individual was developed by modern 
philosophers. Gillon and Childress represent the school of modern thought that remains wary of any justification for paternalistic action; Childress questions whether intervention in the name of saving a life is better than non-intervention in the name of autonomy (16). He maintains that protecting a person, even when his or her actions do not harm another (as for example requiring seat belts), is rarely a sufficient justification for interference with his or her liberty. However, Childress points out that the principle of respect for autonomy has often been misunderstood, misapplied, overweighted and overextended (17). Gillon cautions against paternalistic physicians who impose their judgment on the basis that they are maximizing their patients' autonomy when respect for autonomy demands only adequate autonomy on the part of the patients. Autonomy he finds, takes priority over the beneficence. In their approach, Childress and Gillon differ from contemporary thinkers who defend medical paternalism and cite the physicians' role as healers, their domination of interactions with patients, and their duty to perform medically indicated treatment as rationales for overriding respect for autonomy. Although they vary on the details of dependence on the professional this group labels the idea that an individual is autonomous a philosophical abstraction (18).

Discussing the physician's autonomy in carrying out his professional duties, the play makes a distinction between killing and letting a person die.

Hill: I'm sure it is morally wrong for anyone to try to hand the responsibility for their death to anyone else. And it's wrong to accept that responsibility, but Ken isn't trying to do that (19).

Dr Emerson: ... he [Ken] would die if we did that [let him leave a health care facility].

Hill: He knows that. It's what he wants.

Dr Emerson: And you are asking me to kill my patient? ... It's impossible (20).

Ken: My Lord, I am not asking anyone to kill me. I am only asking to be discharged from this hospital (21).

Childress dwells on the moral distinction between active and passive roles in regard to killing. Although he finds a presumption in favour of prolonging life, the contemporary ethicist recognizes a patient's moral right to refuse treatment. He maintains that society should prohibit killing but authorize allowing to die in certain cases, such as when the patient in consultation with physician decides that the proposed treatment is not acceptable. Emphasizing that the life-death decisions should be made only in terms of the patient's best interest, Childress notes that few people dispute the moral legitimacy of directly hastening death to relieve pain and suffering
(22). Gillon, who generally favours the opinion that respect for autonomy only encompasses the obligation to desist from interfering with a person's autonomous choice, adds that people disagree on who falls within the scope of the moral obligation to desist from killing one another (23).

The play deals with the allocation of social resources which may, potentially, constrain respect for autonomy. The subject is broached in this interchange between John, the orderly, and the nurse.

fohn: How much does it cost to keep him here? Hundreds of pounds a week.

Nurse: That's not the point.

fohn: In Africa, children die of measles. It would cost only a few pounds to keep them alive. There's something crazy somewhere.

Nurse: That's wrong too - but it wouldn't help just letting Mr Harrison die (24).

fudge: I can't accept that it is undignified for society to devote resources to keeping someone alive. Surely it enhances that society (25).

The potential conflict between respect for autonomy and the allocation of social resources is also treated more by modern thinkers than the classicists. Gillon, referring to the fair distribution of scarce beneficial resources as distributive justice, emphasizes that a resource used to benefit one person affects the health care resources available for others. Unless the unequal distribution is justified, Gillon notes, there is a potential problem in justice (26). Childress, also acknowledging that equal access to medical care is morally defensible and even mandatory, notes that there is a need to establish priorities for the allocation of limited health care resources (27). He identifies problems of 'macroallocation' (the allocation of resources to medical care as it conflicts with the pursuit of other social goods such as improving the environment) and 'microallocation' (allocation within the health care sector such as the symbolic value of rescue efforts). Questioning the relevant standards for allocation policies, and aware of the difficulties, Childress enjoins physicians from making allocation choices. His concern has been extended by a school of ethicists who fear that making a value judgment on the cost of keeping a patient alive would begin a slippery slope down which ethical standards would slide.

Clark's play focuses on the relationship between the law and the moral requirement to respect for autonomy.

Hill: ... I ought to warn you [Ken] that Dr Emerson is likely to take steps to have you admitted here as a person needing treatment under the Mental Health Act of 1959. This means that he can keep you here and give you what treatment he thinks fit (28). 
Dr Emerson: ... I have every confidence that the law is not such an ass that it will force me to watch a patient of mine die unnecessarily.

Hill: We are just as confident that the law is not such an ass that it will allow anyone arbitrary power (29).

The philosophers under discussion did not extensively examine the intersection of law, medicine and philosophy highlighted by Clark's play. Kant recognizes a moral law rather than the law of the state. Gillon cites the British Mental Health Act (under which Ken's doctors claim the right to continue his hospitalization) which states that an adult's decision may be overridden if he is sufficiently mentally ill (30). Other philosophers discuss specific issues such as legalized euthanasia and the legitimate conditions under which a person can kill another. Generally they agree that the courts must balance interests of the state with individual liberty rather than assume that autonomy is absolute.

\section{The intrinsic value of human life}

There is also tension between the principle of respect for autonomy and the intrinsic value of human life. The play focuses on the ultimate expression of autonomy, the right to commit suicide.

Ken: I don't wish to die ... Nor do I wish to live at any price. Of course I want to live, but as far as I am concerned I'm dead already. I merely require the doctors to recognize the fact. I cannot accept this condition constitutes life in any sense at all ... Any reasonable definition of life must include the idea of being self-supporting ... whilst I am here [in the hospital] everything is geared just to keeping my brain active, with no real possibility of it ever being able to direct anything. As far as I can see, that is an act of deliberate cruelty (31).

Ken: But I don't want to become happy by becoming the computer section of a complex machine (32).

Fudge: I'm sorry. I understand how you [Dr Emerson] must feel ... If ever I have a road accident, I hope it is in this town and I finish up here (33).

Dr Barr, although he testified that his patient was capable of making a rational decision, indicated that Ken made the 'wrong' choice (34).

Hill: Perhaps we ought to make suicide respectable again. Whenever anyone kills himself there's a whole legal rigmarole to go through ... and it all seems designed to find someone or something to blame. Can you ever recall a coroner saying something like: 'We've heard all the evidence of how John Smith was facing literally insuperable odds and he made a courageous decision. I record a verdict of a noble death?' (35).

Consistent with his broad definition of autonomy, $\stackrel{\overrightarrow{\vec{S}}}{\vec{P}}$ Kant sometimes referred to suicide as an expression $\bar{C}$ of the individual's desire for greater autonomy or self-control over his own death. He acknowledged that destroying oneself requires courage and strength of soul, and considered taking one's own life morally के acceptable, more acceptable than living dishonourably (36). Kant added that a person is morally obliged to allow external forces to take his or $\vec{\omega}$ her life away - even if actively taking his or her own life is morally questionable - in cases where dementing illness would lead to a loss of rationality and lack of self-respect (37). In other writings, however, Kant argued that there is an intrinsic value to preserving life, so great that it prohibits $v$ intentionally destroying oneself, 'even to avoid the 음 madness caused by rabies'. Because of the distinction between man's 'animal life' and his 'moral life', Kant wrote that 'No matter what torments I have to suffer, I can live morally' (36). Kant's ambiguity suggests that he thought about taking one's own life more in terms of the reason for committing suicide than as an expression of human autonomy.

Childress reiterated Kant's concern that sanctioned suicide would cheapen life and bypass principles more important than autonomy. He warned that 'sometimes in focusing too narrowly on rights, we lose sight of what is right, dignified, courageous and honourable. Acts may be substantially autonomous, but, at the same time, irresponsible or deficient in such virtues as courage. Even if a person is able or has the right to kill himself, that person should consider whether suicide is the admirable thing to do' (38).

\section{Conclusion}

The ethical principle of respect for personal autonomy, and its proper application within medical ethics is the focus of Brian Clark's play Whose Life Is o It Anyway? Putting this principle into effect, as Ken found, causes conflict with several other moral concerns. Kant and Mill broadly defined the scope of respect for autonomy. Gillon and Childress, although they generally favour respect for an individual's autonomy, see this respect as individualized and context-related. They maintain that the autonomous human being is to some extent self-determining but limited by others' autonomy and perhaps further moral constraints. Although neither school of philosophers provides definitive guidelines, they offer a framework for decisionmaking.

Margaret Norden, $M A, M L S, B A$, received her Bachelor of Arts from Wellesley College, Wellesley, 
Massachusetts; her Masters in Library Science from Simmons School of Library Science, Boston, Massachusetts, and her Master of Arts in Humanities from Marymount University, Arlington, Virginia, USA. She is currently Reference Librarian at Marymount University.

\section{References}

(1) Clark B. Whose Life Is It Anyway? New York: Dodd, Mead, 1979.

(2) See reference (1): 76-77.

(3) See reference (1): 143.

(4) Brazier M, Lobjoit M. Protecting the vulnerable. New York: Routledge, 1991: 102.

(5) See reference (4): 85.

(6) See reference (1): 43 .

(7) See reference (1): 82.

(8) See reference (1): 132.

(9) See reference (1): 144.

(10) See reference (1): 95-96.

(11) Monahan J. John Stuart Mill on the liberty of the mentally ill. American journal of psychiatry 1977; 134: 429.

(12) See reference (4): 155. For example, Henry Lesser holds the physician morally accountable for providing information in a manner appropriate to the patient's education or mental competence.

(13) See reference (1): 38.

(14) See reference (1): 138.

(15) Guyer P. The Cambridge companion to Kant. Cambridge: CUP, 1992: 384.

(16) See reference (4): 126.
(17) Childress, J. The place of autonomy in bioethics. Hastings Center report 1991; 20: 12-17.

(18) See reference (4): Campbell A. 'Dependency revisited': 101-112.

(19) See reference (1): 103.

(20) See reference (1): 80.

(21) See reference (1): 140.

(22) Childress, J. Priorities in biomedical ethics. Philadelphia: Westminster Press, 1981: 43.

(23) Gillon R, Lloyd A, eds. The four principles revisited a reappraisal. Principles of health care ethics. Chichester and New York: Wiley, 1994: 319-333.

(24) See reference (1): 32-33.

(25) See reference (1): 143.

(26) See reference (4): 66 and also, for example Danis M and Churchill $L$ who offer the concept of citizenship as a framework for solving this moral dilemma in Autonomy and the common weal, Hastings Center report $1991 ; 21,1: 25-31$.

(27) See reference (22): 74-97.

(28) See reference (1): 85.

(29) See reference (1): 127.

(30) See references (4): 57 and (23): 329.

(31) See reference (1): $139-140$.

(32) See reference (1): 69.

(33) See reference (1): 33.

(34) See reference (1): 136.

(35) See reference (1): 102.

(36) Donnelly J. Suicide: right or wrong. Buffalo: Prometheus Books, 1990: 54.

(37) Sullivan R. Immanuel Kant's moral theory. Cambridge: CUP, 1989: 355.

(38) Carpenter B. A review and new look at ethical suicide in advanced age. The gerontologist 1993; 33: 359-372.

\section{News and notes}

\section{Annual Intensive Course on Medical Ethics}

The Annual Intensive Course on Medical Ethics will be held from 11-15 September, 1995 at Imperial College, London.

It provides a multidisciplinary introduction to philosophical medical ethics for medical and nursing teachers, medical practitioners, members of ethics committees and medical administrators.

The course is organised in collaboration with the Institute of Medical Ethics, and directed by Dr Raanan Gillon, Editor of the fournal of Medical Ethics and Director of the Imperial College Health Centre.
Leading international authorities in medical ethics will lead small and large groups, give lectures and take seminars. Participant ratings over the last ten years have consistently given an overall course rating of better than 9 out of 10 satisfaction.

PGEA approval has been sought for 1995.

For further details, please contact: Sally Verkaik, The Continuing Education Centre, Imperial College, Room 558 Sherfield Building, London SW7 2AZ. Tel: +UK (0)171 594 6881/2; fax: +UK (0)171 594 6883, Email: cpd@ic.ac.uk 